\title{
Isolation, partial purification and characterization of thermophilic uricase from Pseudomonas otitidis strain SN4
}

\author{
Nor Sahslin Irwan Shah Lee, Hamidreza Mansouri Khosravi, Norahim Ibrahim and Shafinaz Shahir \\ Department of Biosciences and Health Sciences, Faculty of Biosciences and Medical Engineering, Universiti Teknologi \\ Malaysia, 81310 UTM Skudai, Johor, Malaysia. \\ Email: shafinazshahir@utm.my
}

Received 2 October 2014; Received in revised form 11 April 2015; Accepted 11 May 2015

\begin{abstract}
Aims: The present study aimed at isolating new source of uricase producers from Malaysian hot springs together with partial purification and characterization of thermophilic uricase from novel strain.

Methodology and results: A bacteria strain, designated as SN4, was found to have the ability to degrade uric acid. 16S rRNA analysis identified SN4 as Pseudomonas otitidis. Uricase was then extracted from SN4 and purification was performed via ammonium sulphate precipitation. The effects of temperature, $\mathrm{pH}$ and metal ions on partially purified uricase were evaluated. Results showed that $70 \%$ ammonium sulphate concentration gave the highest uricase activity at $4.18 \mathrm{U} / \mathrm{mL}$ compared to other concentrations. The molecular weight of the partially purified uricase was 33 kilodalton $(\mathrm{kDa})$. The optimum temperature for uricase was $45^{\circ} \mathrm{C}$ and its activity was highest at $\mathrm{pH}$ 8.0. Calcium ions and copper ions enhanced uricase activity while cobalt ions reduced uricase activity.

Conclusion, significance and impact of study: Isolation and investigation of uricase producers from new sources such as thermophiles would increase availability and thermal stability of the uricase that could be used for significant purposes such as in biochemical and clinical applications.
\end{abstract}

Keywords: Uricase, uric acid, Pseudomonas otitidis, hot springs

\section{INTRODUCTION}

Uricase or formerly known as urate oxidase (E.C. 1.7.3.3) oxidizes uric acid into a more soluble form which is allantoin. This enzyme is mainly found in mammals (Keilin, 1959), plants (Montalbini et al., 1997), fungi, (Montalbini et al., 1999), yeasts (Adamek et al., 1990) and bacteria (Yamamoto et al., 1996). Uricase has been used as a diagnostic reagent in clinical and biochemical fields for measurement of uric acid in blood and other biological fluids.

Uric acid is a final product of purine catabolism in human body and excreted out by the kidneys. However, lack of functional uricase and excretion of uric acid lead to various health problems such as gout, hyperuricemia, cardiovascular risk as well as renal failure (Anderson and Vijayakumar, 2011).

Uricase has been isolated from various types of bacteria such as Escherichia coli (Nakagawa et al., 1996), Brevibacterium (Kida and Kunihisa, 1966), Micrococcus, Bacillus sp. including Bacillus fastidiosus (Bongaerts et al., 1978), B. pasteurii (Christians and Kaltwasser, 1986) and $B$. subtilis (Huang and $\mathrm{Wu}, 2004$ ) and Pseudomonas sp. (Ishikawa et al., 2004). A recombinant uricase from $A$. flavus expressed in Saccharomyces cerevisiae known as
Rasburicase has been found able to act rapidly and safely in the treatment of gout and hyperuricemia (Bomalaski and Clark, 2004).

Yazdi et al. (2006) claimed that although uricase produced from many sources, due to its increasing importance for treatment and diagnosis, it is still necessary to screen new sources of uricase producers. Isolation and identification of microorganisms from different sources could contribute to the discovery of potential uricase suited for other biochemical diagnosis and clinical analysis.

Temperature has a great effect on enzyme activity and it is important to withstand with high temperature. Thus, thermostability enzymes will have advantages in transportation and storage. In addition, thermostability enzyme is crucial in clinical applications. Suzuki et al. (2004) notes that although many uricases have been isolated from microorganisms, their thermostabilities have been reported to be low. The use of thermostable uricase is desirable particularly for diagnostic purposes.

The objectives of this study were to isolate new sources of uricase producers from Malaysian hot springs. Considering that this enzyme has potential value in applications, the present study was undertaken to partially purify uricase. The optimum conditions for uricase from 
SN4 were also determined by function of temperature, $\mathrm{pH}$ and metal ions. To our knowledge this is the first report on the isolation of thermophilic uricase from $P$. otitidis isolated from hot springs.

\section{MATERIALS AND METHODS}

\section{Sampling}

Hulu Langat, Selangor, Malaysia was chosen as the hot springs site for microorganism isolation. The temperature of the sampling site is approximately $74{ }^{\circ} \mathrm{C}$. Water and biomat samples were kept in sterile bottles and kept in dry ice and stored in cold room until used.

\section{Isolation and screening of bacterial strain}

Water and biomat samples were aseptically inoculated into sterile $(0.8 \% \mathrm{w} / \mathrm{v})$ uric acid broth, and then incubated at $37{ }^{\circ} \mathrm{C}$ in a shaking incubator. The uric acid medium contained $0.8 \%(\mathrm{w} / \mathrm{v})$ uric acid, $0.01 \%(\mathrm{w} / \mathrm{v}) \mathrm{NaCl}, 0.2 \%$ $(\mathrm{w} / \mathrm{v}) \mathrm{K}_{2} \mathrm{HPO}_{4}, 0.05 \%(\mathrm{w} / \mathrm{v}) \mathrm{KH}_{2} \mathrm{PO}_{4}$, and $0.01 \%(\mathrm{w} / \mathrm{v})$ $\mathrm{CaCl}_{2}$. The $\mathrm{pH}$ was adjusted to 7.5. The culture was then streaked onto Luria-Bertani agar (LBA) plate and incubated at $37^{\circ} \mathrm{C}$ for $24 \mathrm{~h}$. Repeated streaking of bacterial colonies was performed onto new agar plate till pure colonies were isolated. All the isolates were further screened for their ability to degrade uric acid on uric acid agar plate. Screening was conducted by pipetting $3 \mu \mathrm{L}$ of overnight culture onto uric acid plates. The plates were incubated at $37{ }^{\circ} \mathrm{C}$ for $24 \mathrm{~h}$. The clearing zone was measured after $24 \mathrm{~h}$ of incubation indicating uric acid degradation.

\section{Identification of bacterial strain}

A DNA extraction kit from Promega was used for genomic DNA extraction. The 16s rRNA gene of the uric acid degrading bacteria was amplified using the forward primer 5'- AGAGTTTGATCCTGGCTCAG-3' and reverse primer 5'-AAGGAGGTGATCCAGCCGCA-3'. The amplification process was conducted using the following PCR programmes: initial denaturation for $4 \mathrm{~min}$ at $95{ }^{\circ} \mathrm{C}$, denaturation for $30 \mathrm{sec}$ at $95^{\circ} \mathrm{C}$, annealing for $60 \mathrm{sec}$ at $55^{\circ} \mathrm{C}$, extension for $4 \mathrm{~min}$ at $72{ }^{\circ} \mathrm{C}$ and final extension for $10 \mathrm{~min}$ at $72{ }^{\circ} \mathrm{C}$. This cycle was repeated until 30 times and held at $4{ }^{\circ} \mathrm{C}$. The purified PCR product was sent to First Base Laboratories Sdn. Bhd. (Malaysia) for sequencing. The sequence obtained from sequencing was analyzed using the Basic Local Alignment Search Tool (BLAST) to identify the species. Phylogenetic trees of SN4 were then constructed and established using the Ribosomal Database Project (RDP) to determine the phylogenetic relation.

\section{Preparation of crude intracellular uricase}

SN4 was grown overnight at $37^{\circ} \mathrm{C}, 150 \mathrm{rpm}$. Cells were harvested by washed twice in an equal volume of $0.9 \%$ $(\mathrm{w} / \mathrm{v})$ saline solution and centrifuged at $8000 \mathrm{rpm}$ for 15 $\min$ at $4{ }^{\circ} \mathrm{C}$. The cells were then resuspended in $0.1 \mathrm{M}$ borate buffer $(\mathrm{pH} 8.5)$ and disrupted by an ultrasonic device at $5 \%$ amplitude at $4{ }^{\circ} \mathrm{C}$ to lease the enzyme. Disrupted cells were then centrifuged again at same condition.

\section{Partial purification of enzyme}

The inoculum was grown in four litres of uric acid medium until late exponential phase. The culture was then harvested via centrifugation and washed twice with $50 \mathrm{mM}$ phosphate buffer $(\mathrm{pH}$ 7.5). The cells were then resuspended with $0.1 \mathrm{M}$ phosphate buffer $(\mathrm{pH} 7.0)$ at $4{ }^{\circ} \mathrm{C}$ and disrupted by ultrasonic device at $5 \%$ amplitude at 4 ${ }^{\circ} \mathrm{C}$. Partial purification of uricase enzyme was then achieved by ammonium sulphate precipitation followed by dialysis. The cell free extract was saturated with solid ammonium sulphate up to $80 \%$. The precipitate from $30 \%-80 \%$ fractions saturation was then centrifuged (40 min, $8000 \mathrm{rpm}$ at $4{ }^{\circ} \mathrm{C}$ ) and pellet was collected for further analysis. The enzyme mixture was dissolved in a buffer of 2:1 (volume of the buffer:weight of the precipitate) ratio and transferred to a dialysis bag. The content was immersed in sodium phosphate buffer and continuously stirred using a magnetic stirrer for $24 \mathrm{~h}$. The phosphate buffer was changed three times during the process in order to obtain proper purification. The purified enzyme was then collected for further analysis (Anderson and Vijayakumar, 2011).

\section{Molecular mass determination}

The relative molecular mass of the uricase was determined by SDS-PAGE with $10 \%$ polyacrylamide gels (Laemmli, 1970). The sizes of the protein were estimated by comparing them with marker proteins of known molecular weight. Samples of crude enzyme, 30\%, 40\% and $70 \%$ ammonium sulphate precipitated enzyme solution were loaded in the well and ran at constant voltage of $150 \mathrm{~V}$ for $45 \mathrm{~min}$. The protein was then stained with Pierce Imperial ${ }^{\mathrm{TM}}$ Protein Stain for $1 \mathrm{~h}$ and destained in distilled water for overnight.

\section{Enzyme assay for uricase enzyme}

Uricase assay was evaluated spectrophotometrically by complying urate-peroxidase method (Masaru, 1981). The assay was measured based on the oxidation of uric acid into allantoin and $\mathrm{H}_{2} \mathrm{O}_{2}$. Crude enzyme $(0.1 \mathrm{~mL})$ was incubated in $0.6 \mathrm{~mL}$ sodium borate buffer $(\mathrm{pH} 8.5,0.1 \mathrm{M})$ containing $2 \mathrm{mM}$ uric acid, $0.15 \mathrm{~mL}$ 4-aminoantipyrine (30 $\mathrm{mM}), 0.1 \mathrm{~mL}$ phenol $(1.5 \%)$ and $0.05 \mathrm{~mL}$ peroxidase $(15$ $\mathrm{U} / \mathrm{mL}$ ). The mixture was incubated at $37^{\circ} \mathrm{C}$ for $20 \mathrm{~min}$. In order to stop the reaction, $1 \mathrm{~mL}$ of ethanol was added. An absorbance of $540 \mathrm{~nm}$ was read using a spectrophotometer. One unit of uricase was equivalent to the amount of enzyme that produces $1.0 \mu \mathrm{L}$ of $\mathrm{H}_{2} \mathrm{O}_{2}$ per minute. 


\section{Characterization of enzyme}

\section{Effect of $\mathrm{pH}$ and temperature}

The effect of $\mathrm{pH}$ was studied to determine the optimal $\mathrm{pH}$ for uricase production. The $\mathrm{pHs}$ were adjusted to $6.0,6.5$, 7.0, 7.5, 8.0, 8.5, 9.0, 9.5 and 10.0. Uricase productions at different temperatures were also studied. The enzyme reaction was pre-incubated at temperatures between 20 $70{ }^{\circ} \mathrm{C}$ at $5^{\circ} \mathrm{C}$ intervals, and the enzyme solution was then added and incubated for $20 \mathrm{~min}$ at the same temperature to measure its activity.

\section{Effect of metal ions}

Metal ions $\mathrm{Co}^{2+}, \mathrm{Ca}^{2+}, \mathrm{Mn}^{2+}, \mathrm{Mg}^{2+}, \mathrm{Fe}^{2+}, \mathrm{Cu}^{2+}$ and $\mathrm{Zn}^{2+}$ were chosen to study the effect of metal ions in the uricase production. Metal ions were applied at $1 \mathrm{mM}$ final concentration. The enzyme reaction was mixed with different metal ions solution and incubated at $37^{\circ} \mathrm{C}$ for 20 min. The enzyme mixture without metal ions was act as a control. After the incubation period, uricase activity was determined and compared with the control.

\section{RESULTS}

\section{Isolation and screening of uricase degrading microbes}

Water samples from the hot springs were aseptically inoculated into uric acid broth and incubated at $37^{\circ} \mathrm{C}$. The water samples which showed positive growth in uric acid broth were subsequently streaked onto LBA plates. Four different colonies labelled as SN1, SN2, SN3 and SN4 showed significant growth in the presence of uric acid. All isolates were further screened based on the width of clear zone on uric acid agar plates. Figure 1 shows the clearing zones formed on uric acid agar plate after $24 \mathrm{~h}$ incubation. The production of clearing zones indicated that bacterium SN4 was capable of degrading uric acid.

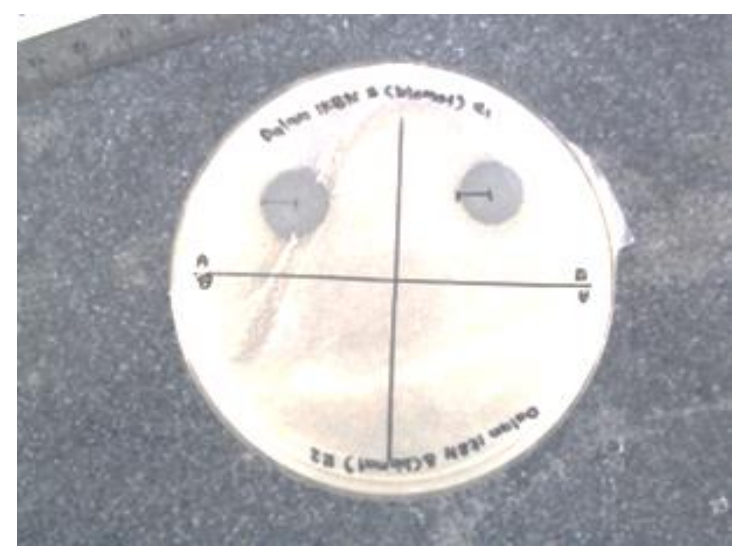

Figure 1: The clearing zone formed on uric acid agar plate after $24 \mathrm{~h}$ incubation. This showed uric acid degradation by bacterium SN4.

\section{Identification of microbes}

The DNA of SN4 was extracted and the 16S rRNA sequences were then analysed. Analysis results showed $99 \%$ similarity of SN4 with $P$. otitidis sequences from $\mathrm{NCBI}$ (National Centre Biotechnology Information) databases. The SN4 nucleotide sequence was submitted to GenBank and assigned the following accession number KM196557. In order to determine the phylogenetic relation of the isolates with $P$. otitidis, a phylogenetic tree was constructed and established using Ribosomal Database Project (RDP). Figure 2 shows the relationship between SN4 and Pseudomonas sp.

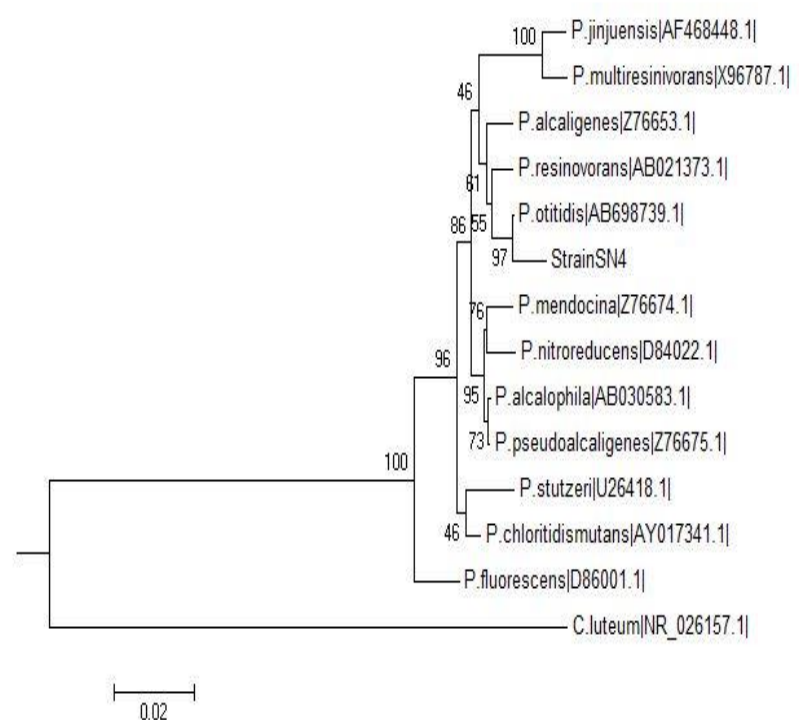

Figure 2: Phylogenetic position of strain SN4 based on $16 s$ rRNA sequence. Numbers at each point of the branch are the bootstrap values.

\section{Partial purification of enzyme}

Uricase produced from SN4 was purified using different concentrations of ammonium sulphate (20\%-80\%). From the results, $70 \%$ ammonium sulphate precipitation showed the highest uricase activity at $4.18 \mathrm{U} / \mathrm{mL}$ while no enzyme activity was detected in $20 \%, 50 \%$ and $60 \%$ ammonium sulphate precipitations. This finding correlated with previous studies where $70 \%$ ammonium sulphate concentration showed the highest activity compared to other fractions (Atalla et al., 2010; Anderson and Vijayakumar, 2011).

\section{Molecular mass determination}

Uricase size from crude extract, $30 \%, 40 \%$ and $70 \%$ of ammonium sulphate precipitation was then estimated by SDS-PAGE. A standard protein marker of known molecular weight was used. Figure 3 shows that the 
estimated uricase molecular weight was approximately 33 $\mathrm{kDa}$. This finding correlates with previous study which claimed that the estimated molecular weight of uricase was between 33-35 kDa (Kai et al., 2007).

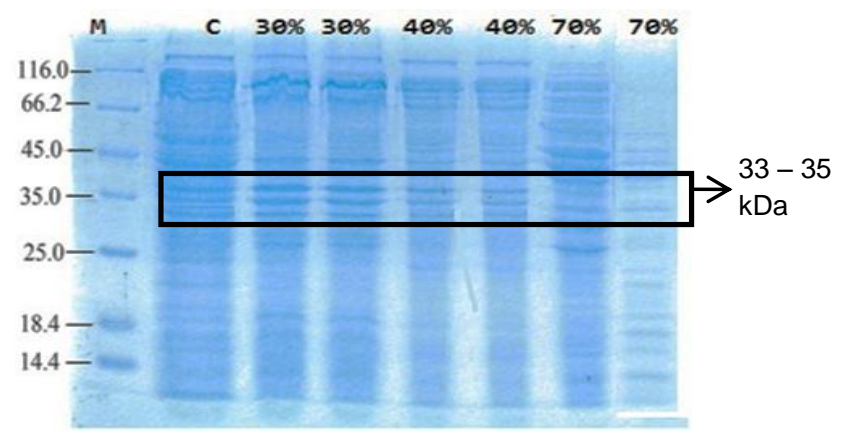

Figure 3: Lane 1, Protein Marker; Lane 2, Crude extract, Lanes 3 and 4, 30\% precipitation; Lanes 5 and 6: 40\% precipitation; Lane 7 and $8,70 \%$ precipitation.

\section{Uricase assay}

Hydrogen peroxide was formed by the action of uricase on uric acid reacts with 4-aminoantipyrine and phenol in the presence of peroxidase. The enzyme reaction produced red colored product known as quinoneimine dye. The formation of quinoneimine dye was proportional to the amounts of uric acid degraded by uricase (Machida and Nakanishi, 1980).

\section{Effect of $\mathrm{pH}$ and temperature}

The purpose of these experiments was to study the trend and determine the optimum $\mathrm{pH}$ and temperature of our enzyme. The experiments relating to $\mathrm{pH}$ and temperature

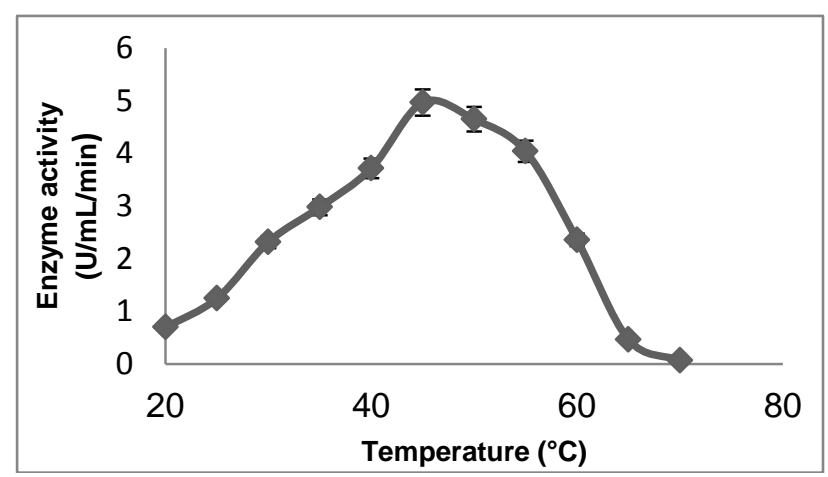

Figure 4: Effect of different temperature on uricase activity. Crude enzyme solution was incubated in water bath at different temperatures for 30 min respectively. The remaining activities were measured after cooling to $37^{\circ} \mathrm{C}$. The values are mean of triplicates with standard error bars. were conducted independently of each other as shown in Figures 4 and 5 . Thus, statistical analysis to indicate significant differences between these two parameters is irrelevant. Figure 4 illustrated that uricase exhibits the highest activity at $45^{\circ} \mathrm{C}$ while Figure 5 showed optimum $\mathrm{pH}$ for uricase activity of SN4 was $\mathrm{pH} 8.0$ and the activities gradually decreased when the $\mathrm{pH}$ increased.

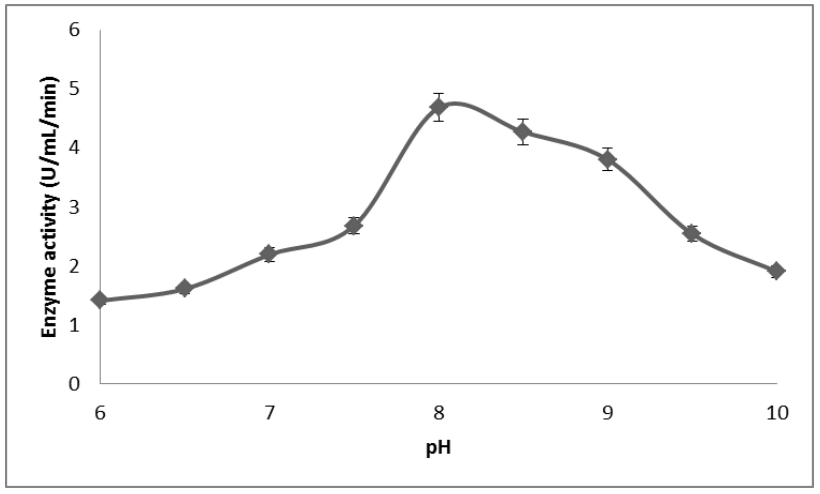

Figure 5: Effect of different $\mathrm{pH}$ on the activity of uricase produced by SN4. The values are mean of triplicates with standard error bars.

\section{Effect of metal ions}

The purpose of this experiment was also to study the trend and determine the effect of metal ions on enzyme activity. Thus, statistical analysis to indicate significant differences between parameters is irrelevant. Figure 6 shows the influence of different metal ions was also studied and results indicated that calcium ions increased the enzyme activity to $140 \%$. In contrast, manganese, magnesium, ferrous and copper ions did not give significant effect to the activity.

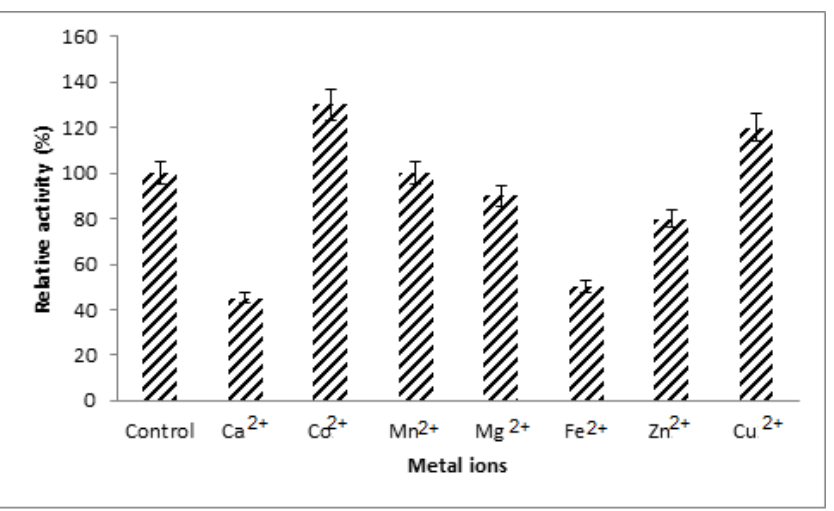

Figure 6: Effect of different metal ions on the activity of uricase produced by SN4. Data shown is the mean values of triplicates with standard error bars. 


\section{DISCUSSION}

In the present study, SN4 was isolated from hot springs and grown in a medium containing uric acid. A positive microbial growth turned insoluble uric acid broth into a colourless soluble solution. From the screening study tested on uric acid agar plate, formation of clearing zone on the uric acid agar plate was observed after $24 \mathrm{~h}$ incubation. From the observation, clear hydrolysis zone was formed around the culture. The appearance of clearing zone indicates that uric acid was hydrolyzed into a more soluble form, and uricase was produced by the isolates. SN4, which formed the largest clearing zone approximately $7 \mathrm{~mm}$ in diameter within $24 \mathrm{~h}$ incubation was selected and used for further studies. SN4 showed 99\% similarity with $P$. otitidis sequences from NCBI (National Centre Biotechnology Information).

Pseudomonas otitidis was firstly proposed and isolated by Clark et al. (2006) from clinical specimens of infected human ears. This strain is a new Pseudomonas species that has been recognized in otic infections in human. $P$. otitidis was also found to be genotypically and phenotypically closely related to Pseudomonas aeruginosa. Pseudomonas otitidis becomes new species that has ability to produce uricase. To the best of our knowledge, this study is the first report on the production of thermophilic uricase from $P$. otitidis which was isolated from hot springs as many previous studies reported uricase were isolated from poultry wastes.

Ammonium sulphate precipitation was performed for the protein solution at different concentrations which were $20 \%(w / v), 30 \%(w / v), 40 \%(w / v), 50 \%(w / v), 60 \%(w / v)$, $70 \%(\mathrm{w} / \mathrm{v})$ and $80 \%(\mathrm{w} / \mathrm{v})$ ammonium sulphate saturation. This was done in order to recognize a suitable concentration of ammonium sulphate in which the protein would aggregate and precipitate out. Dialysis was then performed in order to remove ammonium sulphate from the protein solution as ammonium sulphate can interact with proteins and cause denaturation.

The results given in Figure 3 show that the molecular weight of uricase was estimated to be $33 \mathrm{kDa}$. This finding is in agreement with previous studies (Kai et al., 2007; Anderson and Vijayakumar, 2011) whereby the uricase size was estimated to be in the range of 33-35 $\mathrm{kDa}$. In contrast, a study from Hesham et al. (2004) found a larger size of purified uricase from Pseudomonas aeruginosa which was $68.0 \mathrm{kDa}$ for one subunit while uricase from Bacillus fastidiosus was reported to be 145$150 \mathrm{kDa}$ (Bongaerts and Vogel, 1976).

Most enzymes work optimally at $37^{\circ} \mathrm{C}$. Interestingly, in this study, uricase activity was found to be optimum at $45^{\circ} \mathrm{C}$ (4.97 U/mL.min). The enzyme activity was then decreased at $70{ }^{\circ} \mathrm{C}(0.07 \mathrm{U} / \mathrm{mL}$.min). This was likely due to the high temperature that caused protein denaturation or instability. A study on Gliomastix gueg reported $35^{\circ} \mathrm{C}$ as the optimum temperature for uricase (Mabrouk et al., 2010) while study on Microbacterium sp. strain ZZJ4-1 reported an optimum temperature at $30{ }^{\circ} \mathrm{C}$. The characteristics of thermophilic organisms refer to the capability in producing thermostable enzyme.
Thermophilic enzymes are needed as they can maintain their activity and reduce risk of microbial contamination. Thus, thermophilic enzymes have great interests in commercial and industrial applications (Kuchner and Arnold, 1997).

$\mathrm{pH}$ plays an important role in enzyme function and activity. The point value where the enzyme is most active is known as the optimum $\mathrm{pH}$. The optimum $\mathrm{pH}$ for SN4 was tested and results showed that $\mathrm{pH} 8$ was the optimum $\mathrm{pH}$ where uricase activity reached its highest activity (4.68 U/mL.min). The literatures have reviewed varied optimal $\mathrm{pH}$ for uricase depending on the species producing the enzyme. For example Kai et al. (2007) reported an optimum $\mathrm{pH}$ of 9 for Microbacterium sp. strain ZZJ4-1.

Metal ions play important roles in the biological function of many enzymes. Metal can either act as an electron donor or acceptor. Metal ions can catalyse or inhibit enzyme reaction (Coolbear et al., 1992). In order to study the effect of metal ions on uricase activity, different metal ions were chosen $\left(\mathrm{Co}^{2+}, \mathrm{Ca}^{2+}, \mathrm{Mn}^{2+}, \mathrm{Mg}^{2+}, \mathrm{Fe}^{2+}\right.$, $\mathrm{Cu}^{2+}$ and $\left.\mathrm{Zn}^{2+}\right)$. From this study, it was found that $\mathrm{Ca}^{2+}$ and $\mathrm{Cu}^{2+}$ enhanced the enzyme activity slightly while other metal ions seemed to inhibit the activity. Previous studies reported that $\mathrm{Ca}^{2+}$ enhanced uricase activity (Atalla et al., 2010) whilst another study showed that $\mathrm{Ca}^{2+}$ and $\mathrm{Cu}^{2+}$ ions enhanced the activity of uricase (Hesham et al., 2004). Atalla et al. (2010) suggested that metal ions bind to the uricase and changes the enzyme's activity by stabilization or destabilization the enzyme's conformation.

\section{CONCLUSION}

This study has successfully isolated $P$. otitidis SN4 from Malaysian hot springs able to produce uricase. Interestingly, this is the first report on the production of uricase from $P$. otitidis. Uricase is one of the most important enzymes used in the detection of uric acid in blood and other biological fluids. Thermophilic uricase of $P$. otitidis SN4 has commercial potential to be used in biosensor field particularly for uric acid detection.

\section{ACKNOWLEDGEMENT}

We would like to express our sincere thanks to the Ministry of Education (MOE) for funding the project under Grant University Project (GUP) vote number $03 \mathrm{H} 39$ and Universiti Teknologi Malaysia for the research facilities. The first author would also like to thank MOE for Mybrain15 PhD scholarship.

\section{REFERENCES}

Adamek, V., Suchova, M., Demnerova, K., Kralova, B., Fort, I. and Morava, P. (1990). Fermentation of Candida utilis for uricase production. Journal Industrial Microbiology 6, 85-90.

Anderson, A. and Vijayakumar, S. (2011). Purification and optimization of uricase enzyme produced by 
Pseudomonas aeruginosa. Journal Experimental Science 2(11), 5-8.

Atalla, M. M., Farag, M. M., Eman, R. H., Abd-El-Lataif, M. S. and Nehad, E. A. (2010). Purification and characterization of uricase enzyme produced by Gliomastix gueg. www. Gate2Biotech.com 2(11), 1-13.

Bomalaski, J. S. and Clark, M. A. (2004). Serum uric acid-lowering therapies: where are we in management of hyperuricemia and the potential role of uricase. Current Rheumatology Reports 6, 240-247.

Bongaerts, G. P. A and Vogels, G. D. (1976). Uric acid degradation by Bacillus fastidiosus strains. Journal Bacteriology 125, 689-697.

Bongaerts, G. P. A., Uitzetter, J., Brouns, R. and Vogels, G. D. (1978). Uricase of Bacillus fastidiosus properties and regulation of synthesis. Biochemica et Biophysica Acta 527, 348-358.

Clark, L. L., Dajc, J. J, McLean, C. H., Bartell, J. G. and Stroman, D. W. (2006). Pseudomonas otitidis sp. nov., isolated from pateints with otic infections. International Journal of Systematic and Evolutionary Microbiology 56, 709-714.

Christians, S. and Kaltwasser, H. (1986). Nickel-content of urease from Bacillus pasteurii. Archive of Microbiology 9, 51-55.

Coolbear, T., Whittaker J. M. and Daniel, R. M. (1992). The effect of metal ions on the activity and thermostability of the extracellular proteinase from a thermophilic Bacillus, strain EA.1. The Biochemical Journal 287, 367-374.

Hesham, M. S., Yasser, R., Abdel-Fattah, Y., Gohar, M. and Mohammed, A. E. (2004). Purification and Characterization of extracellular Pseudomonas aeruginosa urate oxidase enzyme. Polish Journal of Microbiology 53(1), 45-52.

Huang, S. and Wu, T. (2004). Modified colorimetric assay for uricase activity and a screen for mutant Bacillus subtilis uricase gene following StEP mutagenesis. European Journal of Biochemistry 271, 517-523.

Ishikawa, J., Yamashita, A., Mikami, Y., Hoshino, Y., Kurita, H. and Hotta, K. (2004). The complete genomic sequence of Nocardia farcinia IFM 10152. Proceedings of the National Academy of Sciences of the United States of America. 101, 14925-14930.

Kai, L., Ma, X. H., Zhou, X. L., Jia, X. M., Li, X. and Guo, K. P. (2007). Purification and characterization of a thermostable uricase from Microbacterium sp. strain ZZJ4-1. World Journal of Microbiology and Biotechnology 24(3), 401-406.

Keilin, J. (1959). The biological significance of uric acid and guanine excretion. Biology Revision 34, 265-296.

Kida, J. and Kunihisa, M. (1966). Studies on bacterial uricase (I) Isolation of uricase producing bacteria and some cultural conditions for production. Journal of Fermentation Technology 44, 789-796.

Kuchner, O. and Arnold, F. H. (1997). Directed evolution of enzyme catalysts. Trends in Biotechnology 15(12), 523-530.
Laemmli (1970). Cleavage of structural proteins during assembly of the head of bacteriophage T4. Nature 227, 680-685.

Mabrouk, M., Hamed, E. R. and Ahmed, N. E. (2010). Purification and characterization of uricase enzyme produced by Gliomastix gueg. Journal Biological Science 2, 1-13.

Machida, Y. and Nakanishi, T. (1980). Purification and properties of uricase from Enterobacter cloacae. Agricultural and Biological Chemistry 44(12), 28112815.

Masaru, S. (1981). Purification and some proeperties of sarcosine oxidase from Corynebacterium sp. U-96. Journal of Biochemistry 89, 599-607.

Montalbini, P., Aguilar, M. and Pineda, M. (1999). Isolation and characterization of uricase from bean leaves and its comparison with uredospore enzyme. Plant Science 147,139-147.

Montalbini, P., Redondo, J., Caballero, J. L., Cardenas, J. and Pineda, M. (1997). Uricase from leaves: its purification and characterization from three different higher plants. Planta 202, 277-283.

Nakagawa, S., Ishino, S. and Teshiba, S. (1996). Construction of catalase deficient Escherichia coli strains of the production of uricase. Bioscience Biotechnology and Biochemistry 60, 415-420.

Suzuki, K., Sakasegawa, S. I. and Misaki, H. (2004). Molecular cloning and expression of uricase gene from Arthrobacter globiformis in Escherichia coli and characterization of the gene product. Journal of Bioscience and Bioengineering 98,153-158.

Yamamoto, K., Kojima, Y., Kikuchi, T., Shigyo, T., Sugihara, K. and Takashio, M. (1996). Nucleotide sequence of the uricase gene from Bacillus sp. TB-90. Journal of Biochemistry 119, 80-84.

Yazdi, M. T., Zarrini, G., Mohit, E., Faramarzi, M. A., Setayesh, N., Sedighi, N. and Mohseni, F. A. (2006). Mucor hiemalis: A new source for uricase production. World Journal of Microbiology and Biotechnology 22(4), 325-330. 